\title{
Cutaneous Melanoma cN3 TNM Finding v7
}

National Cancer Institute

\section{Source}

National Cancer Institute. Cutaneous Melanoma cN3 TNM Finding v7. NCI Thesaurus.

Code C88404.

Cutaneous melanoma with 1 or more metastatic nodes with in transit met(s)/satellite(s).

(from AJCC 7th Ed.) 